Article

\title{
Anti-Aging $\beta$-Klotho Gene-Activated Scaffold Promotes Rejuvenative Wound Healing Response in Human Adipose-Derived Stem Cells
}

\author{
Ashang L. Laiva ${ }^{1,2}$, Fergal J. O’Brien ${ }^{2,3,4}$ and Michael B. Keogh ${ }^{1,2, *}$ \\ 1 Tissue Engineering Research Group-Bahrain, Royal College of Surgeons in Ireland, Adliya, \\ Manama P.O. Box 15503, Bahrain; lluwang@rcsi-mub.com \\ 2 Tissue Engineering Research Group, Department of Anatomy and Regenerative Medicine, Royal College of \\ Surgeons in Ireland, 123 St. Stephen's Green, D02 YN77 Dublin, Ireland; fjobrien@rcsi.ie \\ 3 Trinity Centre for Biomedical Engineering, Trinity Biomedical Sciences Institute, Trinity College Dublin, \\ D02 PN40 Dublin, Ireland \\ 4 Advanced Materials and Bioengineering Research Centre, Royal College of Surgeons in Ireland and Trinity \\ College Dublin, D02 YN77 Dublin, Ireland \\ * Correspondence: mkeogh@rcsi-mub.com
}

check for updates

Citation: Laiva, A.L.; O'Brien, F.J.; Keogh, M.B. Anti-Aging $\beta$-Klotho Gene-Activated Scaffold Promotes Rejuvenative Wound Healing Response in Human

Adipose-Derived Stem Cells. Pharmaceuticals 2021, 14, 1168. https://doi.org/10.3390/ph14111168

Academic Editors: Takehisa Hanawa, Yayoi Kawano, Viorica Patrulea, Mitsutoshi Sato and Olivier Jordan

Received: 29 September 2021 Accepted: 9 November 2021 Published: 17 November 2021

Publisher's Note: MDPI stays neutral with regard to jurisdictional claims in published maps and institutional affiliations.

Copyright: (C) 2021 by the authors Licensee MDPI, Basel, Switzerland. This article is an open access article distributed under the terms and conditions of the Creative Commons Attribution (CC BY) license (https:/ / creativecommons.org/licenses/by/ $4.0 /)$.

\begin{abstract}
Wound healing requires a tight orchestration of complex cellular events. Disruption in the cell-signaling events can severely impair healing. The application of biomaterial scaffolds has shown healing potential; however, the potential is insufficient for optimal wound maturation. This study explored the functional impact of a collagen-chondroitin sulfate scaffold functionalized with nanoparticles carrying an anti-aging gene $\beta$-Klotho on human adipose-derived stem cells (ADSCs) for rejuvenative healing applications. We studied the response in the ADSCs in three phases: (1) transcriptional activities of pluripotency factors (Oct-4, Nanog and Sox-2), proliferation marker (Ki-67), wound healing regulators (TGF- $\beta 3$ and TGF- $\beta 1$ ); (2) paracrine bioactivity of the secretome generated by the ADSCs; and (3) regeneration of basement membrane (fibronectin, laminin, and collagen IV proteins) and expression of scar-associated proteins ( $\alpha$-SMA and elastin proteins) towards maturation. Overall, we found that the $\beta$-Klotho gene-activated scaffold offers controlled activation of ADSCs' regenerative abilities. On day 3, the ADSCs on the gene-activated scaffold showed enhanced (2.5-fold) activation of transcription factor Oct- 4 that was regulated transiently. This response was accompanied by a 3.6-fold increase in the expression of the anti-fibrotic gene TGF- $\beta 3$. Through paracrine signaling, the ADSCs-laden gene-activated scaffold also controlled human endothelial angiogenesis and pro-fibrotic response in dermal fibroblasts. Towards maturation, the ADSCs-laden gene-activated scaffold further showed an enhanced regeneration of the basement membrane through increases in laminin (2.1-fold) and collagen IV (8.8-fold) deposition. The ADSCs also expressed 2-fold lower amounts of the scar-associated $\alpha$-SMA protein with improved qualitative elastin matrix deposition. Collectively, we determined that the $\beta$-Klotho gene-activated scaffold possesses tremendous potential for wound healing and could advance stem cell-based therapy for rejuvenative healing applications.
\end{abstract}

Keywords: anti-aging; $\beta$-Klotho; gene-activated scaffold; adipose-derived stem cells; angiogenesis; matrix deposition; rejuvenative healing

\section{Introduction}

Wound healing is a complex biological process that requires a tight orchestration of multiple cellular events [1]. However, in the aging population, cellular events are disrupted, leading to delayed healing [2]. The disruption in the healing mechanisms arises partly due to the reduced homing of the progenitor cells from the bone marrow and other prevailing metabolic diseases such as diabetes $[3,4]$. In wound management, the application of biomaterial scaffolds is becoming more common as a treatment. Biomaterial scaffolds 
protect the wound from infection, absorb wound exudates, and keep the wound moist to prevent tissue necrosis [5]. Therapeutics can also be loaded into biomaterial scaffolds and promote faster healing in hard-to-heal wounds [1]. However, biomaterial scaffolds alone may not effectively orchestrate the multiple signaling cascades occurring within the wound. Delivering stem cells is sometimes proposed as a solution for moderating the complex signaling events in the wound [6].

Stem cells secrete paracrine factors and can differentiate into cells of multiple tissue lineages [7]. Stem cells are typically delivered into the wound through intradermal injections [6], topical spraying [8], or as tissue-engineered grafts [9]. In recent years, the application of tissue-engineered grafts for chronic wound healing has gradually gained wider acceptance because of their ability to heal wounds rapidly [9-11]. Apligraf ${ }^{\circledR}$ and Dermagraft $^{\circledR}$ are two of the widely used Food and Drug Administration (FDA)-approved bioengineered constructs for chronic wound treatment $[12,13]$. However, the generation of these grafts requires prolonged cell culture to produce high cell numbers [14]. When using stem cells, prolonged culture can increase cellular senescence and diminish the stemness of the stem cells $[15,16]$. Therefore, maintaining the stemness of the stem cells is central to achieving the optimal therapeutic response.

Therapeutic gene delivery to the stem cells using non-viral vectors is a potential strategy to enhance stem cells' functionality [17]. Traditionally, the cells are transfected in 2 D cultures and later transplanted in vivo [18]. However, platforms such as the geneactivated scaffolds, consisting of biomaterial scaffolds functionalized with nanoparticles carrying the therapeutic transgene [19], that our group have been pioneering offer an alternative solution for transfecting the cells within a $3 \mathrm{D}$ environment. This study focused on developing a gene-activated version of the $3 \mathrm{D}$ collagen-chondroitin sulfate (coll-CS) scaffold that has tremendous clinical translation potential, as its composition is similar to that of the Integra's Dermal Regeneration Template (DRT), a clinically approved scaffold for chronic wound healing [20]. We primarily use a cationic polymer called polyethyleneimine (PEI) to condense DNA plasmids encoding for growth factor genes such as the stromal-derived factor- 1 alpha and nerve growth factor and assemble them into charged nanoparticles [21-23]. These charged nanoparticles are then soak-loaded into our coll-CS scaffold to generate the gene-activated scaffolds. Our previous studies have also shown that the PEI-based gene-activated scaffold can cause transient overexpression of the therapeutic transgene in a range of wound-healing cells and promote their regenerative abilities [21,24,25]. Traditionally, the gene-activated scaffold was developed to target host cells and promote local repair [26]. However, emerging evidence indicates that cell-laden gene-activated scaffolds bear superior potency to regenerate complex tissue structures than gene-activated scaffolds alone [27].

Cellular abundance is one of the crucial requirements for the generation of tissueengineered grafts [28]. The adipose tissue is a rich source that can supply a large number of stem cells. The adipose tissue contains as many as 500-times the stem cells for the same mass of bone marrow, a traditional tissue source for stem cell extraction [29]. Moreover, the stem cells can be extracted from the adipose tissue using a minimally invasive liposuction process [29]. Our recent study found that the human adipose-derived stem cells (ADSCs) demonstrate excellent biocompatibility with the coll-CS scaffold. Using a pro-angiogenic gene-activated scaffold further improved the ADSCs' regenerative responses [30]. However, the ADSCs tend to lose their stemness upon expansion [31]. Previously, we found that an anti-aging protein $\beta$-Klotho could significantly improve the proliferation of healthy and diabetic human ADSCs [32]. Most studies generally use the primary variant $\alpha$-Klotho [33-35] and have shown that the protein can increase the lifespan of ADSCs by activating the telomerase transcriptional activity [33]. $\alpha$-Klotho overexpressing MSCs have also been found to exert strong anti-fibrotic effects in kidney injury through the inhibition of $W n t / \beta$-catenin signaling [36]. However, the role of $\beta$-Klotho in stem cells remains relatively unexplored.

Besides the difference in the research focus between the $\alpha$ - and $\beta$-Klotho, the anti-aging Klotho proteins have not yet been fully incorporated into the tissue engineering strategies 
for wound healing. Therefore, in this study, we sought to study the functional impact of a $\beta$-Klotho gene-activated scaffold on human ADSCs for wound healing applications. We first investigated the transcriptional activities of the classical pluripotency factors (Oct-4, Nanog and Sox-2), proliferation marker (Ki-67) and wound healing regulators (TGF- $\beta 3$ and TGF- $\beta 1$ ) in the ADSCs. We then assessed the bioactivity of the conditioned media generated by the ADSCs-laden gene-activated scaffold to evaluate its paracrine potential. Ultimately, we examined the regeneration of basement membrane (fibronectin, laminin, and collagen IV) and scar-associated proteins ( $\alpha$-SMA and elastin) in the ADSCs-laden gene-activated scaffold to evaluate controlled tissue maturation.

\section{Results}

\section{1. $\beta$-Klotho Gene-Activated Scaffold Transiently Enhances Human ADSCs' Stemness and Pro-Reparative Genes}

Gene expression analysis first showed that the ADSCs on the gene-activated scaffold overexpressed the $\beta$-Klotho gene over 172-fold $(p<0.01)$ than the gene-free scaffold group on day 3 (Figure 1A). This finding confirmed the efficient interaction of the ADSCs with the gene-activated scaffold. Analysis of the proliferation marker Ki-67 further confirmed that the ADSCs on the gene-activated scaffold also maintained a robust proliferative capacity over 14 days (Figure 1A).

Having confirmed the overexpression of the anti-aging $\beta$-Klotho gene, we then assessed stem cells' rejuvenation through the activation of "pluripotency" factors in the ADSCs. Overall, we noted a transient regulation of all the three transcription factors over the 14 days (Figure 1B). However, the ADSCs only showed a significant increase in the expression of the Oct- 4 gene that sustained until day 14 . Specifically, the ADSCs showed a 2.5 -fold $(p<0.05)$ increase in the expression of the Oct- 4 gene on day 3 before subsiding to 1.6 -fold $(p<0.05)$ on day 14 relative to the gene-free scaffold group.

The next set of genes we investigated were the transforming growth factors beta 1 and 3, which are crucial for regulating scarless wound healing (Figure 1C). The levels of pro-fibrotic TGF- $\beta 1$ gene in the $\beta$-Klotho overexpressing ADSCs were found to be in par with that of the gene-free scaffold group over the 14 days. However, the levels of anti-fibrotic TGF- $\beta 3$ were significantly ( 3.6 -fold, $p<0.05$ ) elevated during the early days (day 3 ) and, as anticipated, subsided by about 0.4 -fold by day 14 , showing a controlled expression of the regulatory gene.

\section{2. $\beta$-Klotho Gene-Activated Scaffold Enhances the Paracrine Potency of Human ADSCs}

\subsubsection{Pro-Angiogenic Bioactivity}

The bioactivity test of the CM generated by ADSCs-laden gene-activated scaffold first showed that it could temporally control the metabolic activity in HUVECs. Day $3 \mathrm{CM}$ significantly enhanced the metabolic activity in HUVECs, while the use of aged CM from day 14 significantly reduced the HUVEC's metabolic activity (Figure 2A). Having observed this, we then tested the pro-angiogenic impact of the CM from day 3 and 14 on the HUVECs seeded on Matrigel. As anticipated, day $3 \mathrm{CM}$ from the gene-activated scaffold group significantly $(p<0.05)$ enhanced HUVEC tubule formation capacity and their branching (Figure 2B). However, no further rise in the angiogenic activity occurred with day $14 \mathrm{CM}$ compared to that of the day $3 \mathrm{CM}$. Also, the day $14 \mathrm{CM}$ from both the groups exhibited similar pro-angiogenic efficiency (Figure 2C). Collectively, our finding indicates that the gene-activated scaffold transiently expedites ADSCs' pro-angiogenic response. 
A $\quad \beta$-Klotho activation and cell proliferation markers

$\square$ hADSCs/gene-free scaffold

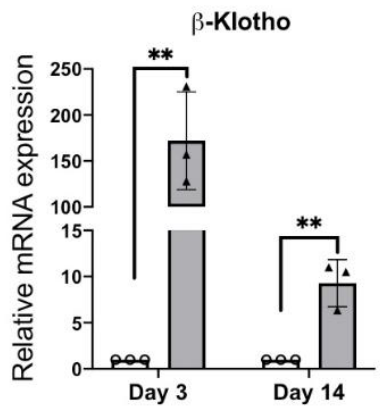

$\square \quad$ hADSCs/ $\beta$-Klotho gene-activated scaffold

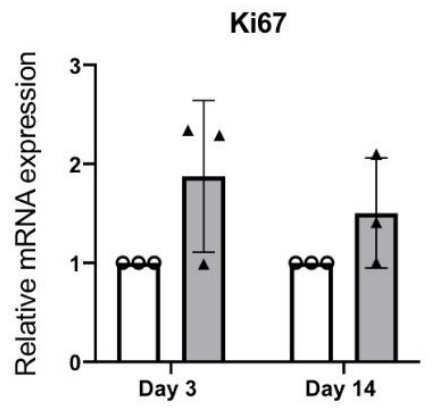

Stem cell pluripotency markers

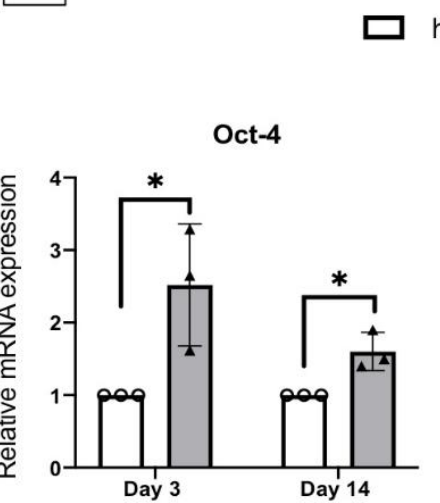

hADSCs/gene-free scaffold $\square \quad$ hADSCs/ $\beta$-Klotho gene-activated scaffold
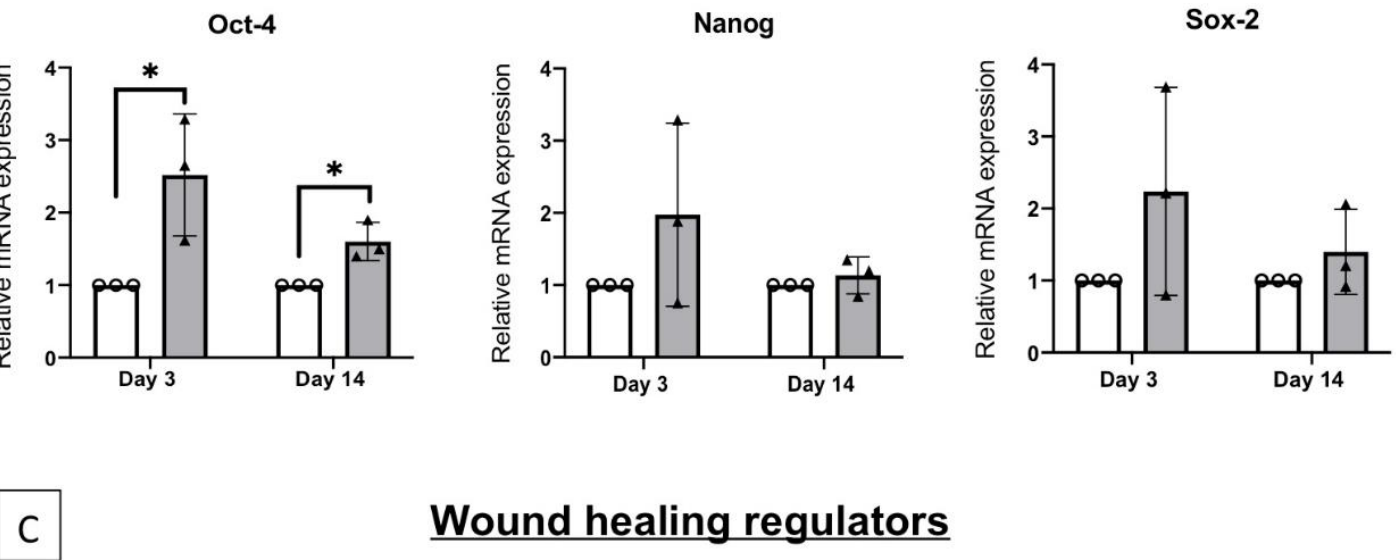

Wound healing regulators
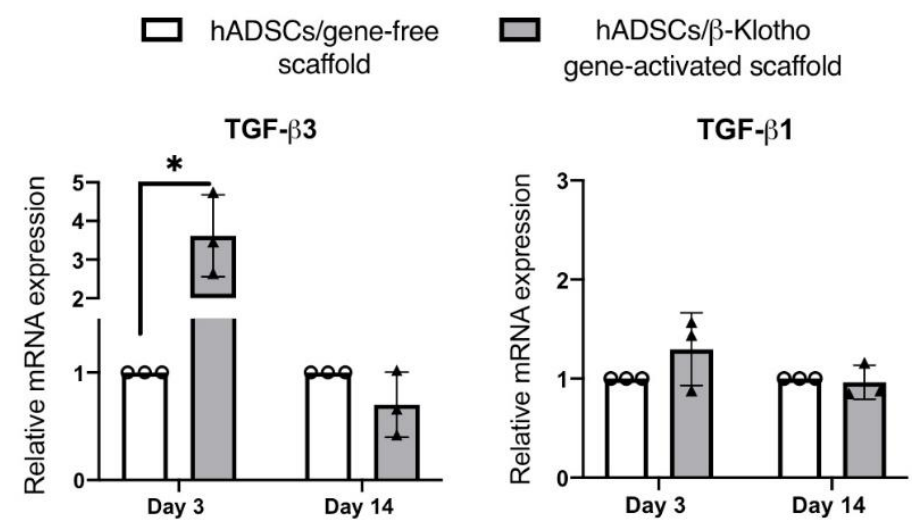

Figure 1. Transcriptional activation of functional genes in the human ADSCs by $\beta$-Klotho gene-activated scaffold on day 3 (early) and day 14 (aged). (A) The ADSCs on the gene-activated scaffold showed a transient, high-level overexpression of the therapeutic transgene $\beta$-Klotho until 14 days. Ki-67 marker indicates that the ADSCs proliferated well within the gene-activated scaffold. (B) $\beta$-Klotho overexpression significantly induced the activation of pluripotency factor Oct-4 in the ADSCs while maintaining basal levels of Nanog and Sox-2. (C) Increased activation of the stemness in the ADSCs was further associated with a robust early activation of the anti-fibrotic gene TGF- $\beta 3$, while maintaining basal levels of the pro-fibrotic TGF- $\beta 1$. ${ }^{* *}$ and ${ }^{*}$ indicates $p<0.01$ and $p<0.05$ respectively. Data represents mean \pm standard deviation $(n=3)$. 

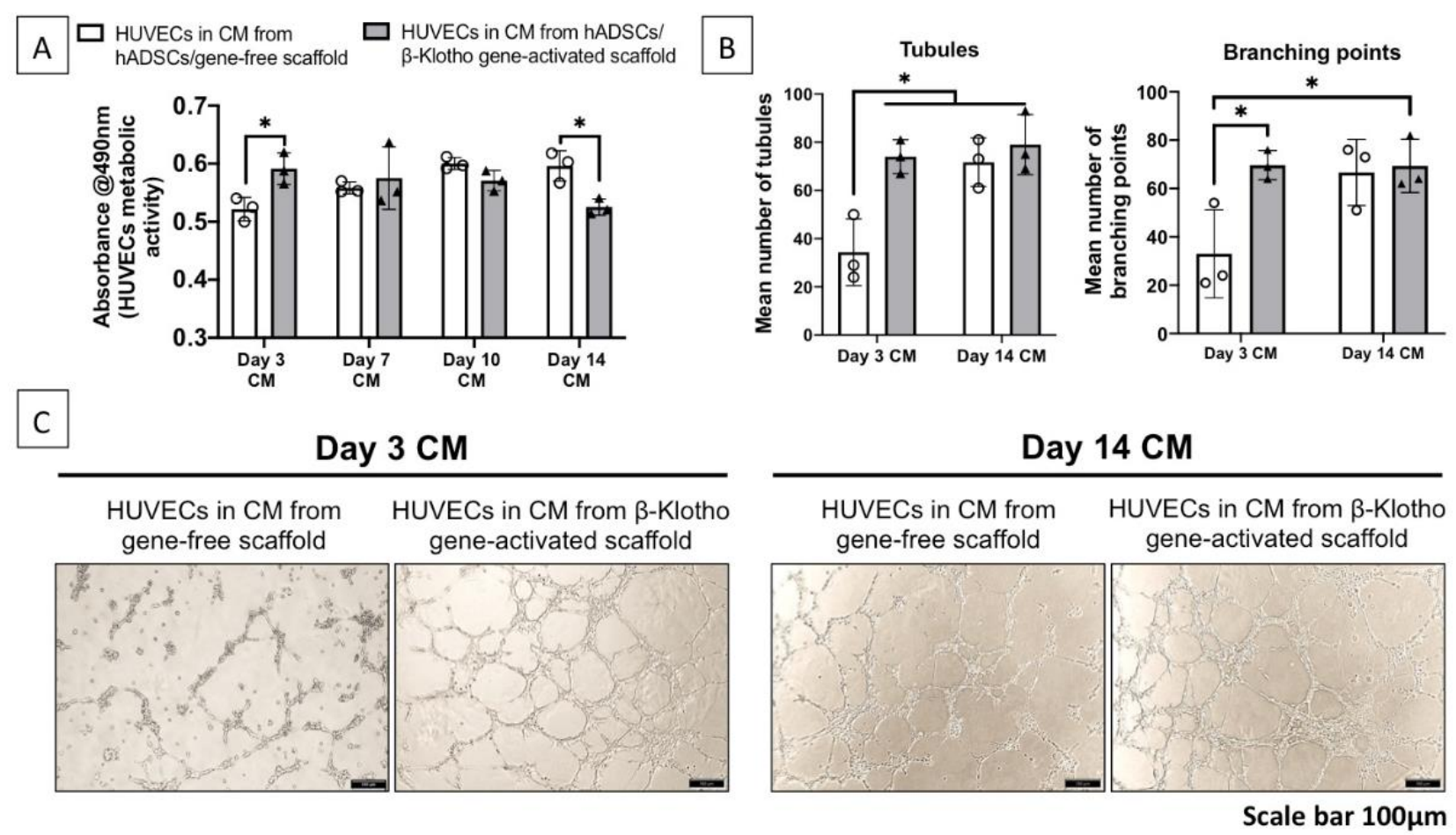

Figure 2. Pro-angiogenic paracrine bioactivity of the ADSCs-laden gene-activated scaffold CM. (A) CM produced by the ADSCs-laden gene-activated scaffold over the 14 days demonstrated an ability to temporally control HUVECs' metabolic activity. (B) Day 3 CM from the gene-activated scaffold group significantly enhanced endothelial tubule formation and its branching compared to that of the gene-free scaffold group. (C) Tubule formation and branching of endothelial cells $6 \mathrm{~h}$ post-exposure to CM from the ADSCs seeded gene-activated and gene-free scaffold. * indicates $p<0.05$. Data represents mean \pm standard deviation $(n=3)$.

\subsubsection{Dermal Fibroblast Healing and Maturation}

One of the findings from the angiogenesis study is that as the ADSCs-laden geneactivated scaffold matures, it no longer promotes angiogenesis. Furthermore, on day 14, their angiogenic potency was similar to that of the gene-free scaffold group (Figure 2B,C). Therefore, we investigated the influence of aged day $14 \mathrm{CM}$ on dermal fibroblast wound closure. Similar to the angiogenesis study result, both groups demonstrated similar levels of fibroblast wound closure with day $14 \mathrm{CM}$. Specifically, both the groups healed the wound by approximately $40 \%$ in $12 \mathrm{~h}$ (Figure $3 \mathrm{~A}$ ). This finding revealed that during maturation, the gene-activated scaffold group supports but does not promote dermal fibroblasts' wound closure.

Nevertheless, as the fibroblasts were stimulated with aged CM, we studied if the $\mathrm{CM}$ influences the expression of matrix proteins involved in wound maturation. As anticipated, dermal fibroblasts stimulated with $\mathrm{CM}$ from the gene-free scaffold group abundantly expressed the pro-fibrotic collagen I protein (Figure 3B). On the contrary, fibroblasts stimulated with CM from the gene-activated scaffold group demonstrated $50 \%$ lower expression $(p<0.05)$ of the collagen I protein. Meanwhile, both the groups lacked the expression of anti-fibrotic collagen III, and no differences were observed between the two groups. Taken together, it implies that the gene-activated scaffold enhances ADSCs' wound modulatory response during maturation. 


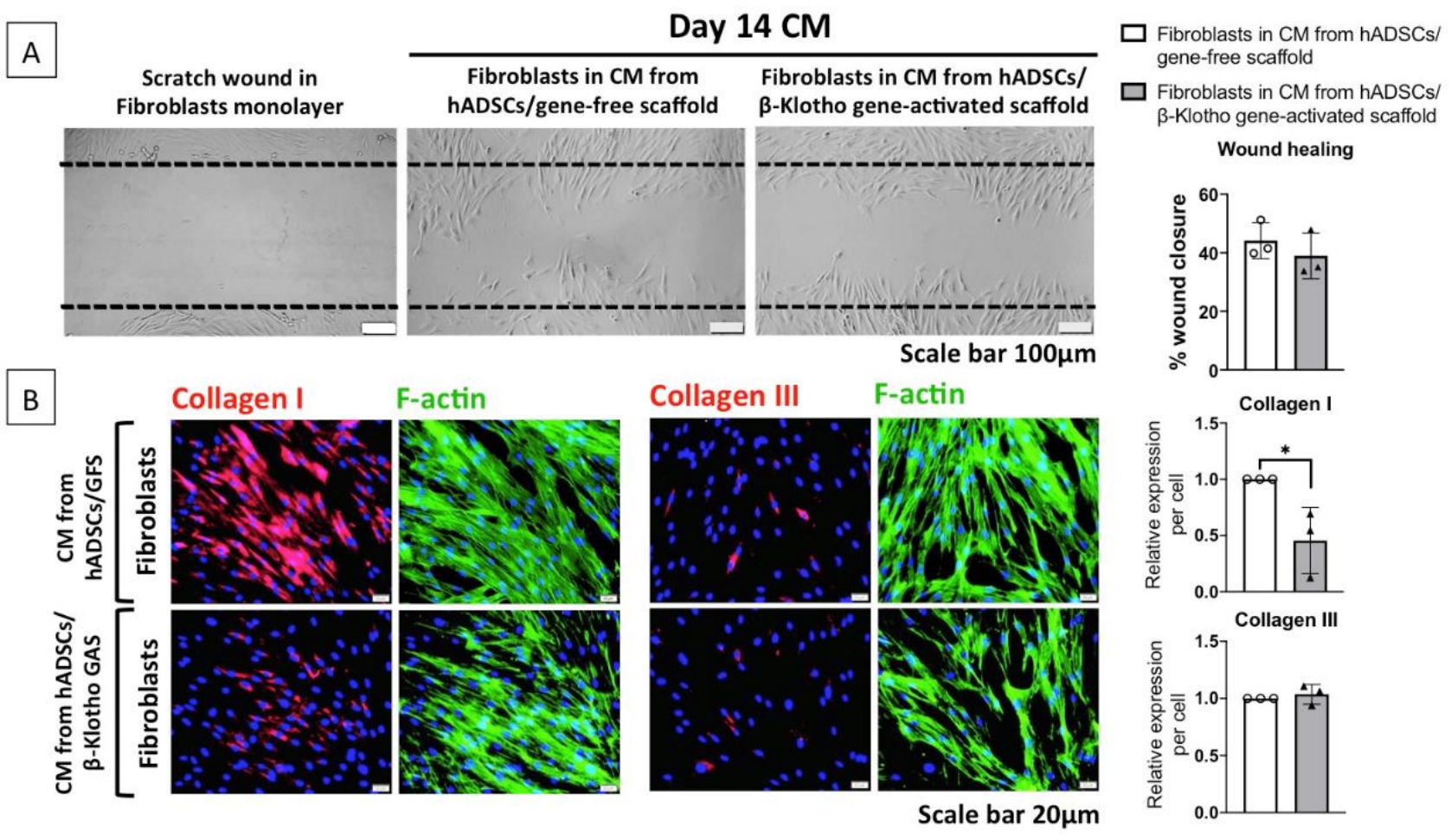

Figure 3. Paracrine influence on dermal healing and maturation. (A) Aged day $14 \mathrm{CM}$ from both the groups exerted similar levels of wound closure activity in human adult dermal fibroblasts by approximately $40 \%$ in $12 \mathrm{~h}$. (B) CM from the gene-activated scaffold significantly reduced the expression of pro-fibrotic collagen I in the fibroblasts. ${ }^{*}$ indicates $p<0.05$. Data represents mean \pm standard deviation $(n=3)$. In Figure 3B, GAS and GFS stand for gene-activated scaffold and gene-free scaffold respectively.

2.3. $\beta$-Klotho Gene-Activated Scaffold Enhances Basement Membrane Regeneration with Improved Anti-Fibrotic Response in Human ADSCs

Having observed the gene-activated scaffold's controlled stimulation of ADSC s' functionality, we ultimately investigated the ADSCs' response towards the regeneration of dermal matrices and proteins. The gene-activated scaffold robustly enhanced the regeneration of ADSCs' basement membrane. Specifically, the gene-activated scaffold significantly promoted the deposition of basement membrane components laminin and collagen IV (Figure 4A). After the semi-quantitative analysis, we also noted that the matrix deposition followed a trend relative to the gene-free scaffold group. The trend as observed was fibronectin $(1.0$-fold) < laminin $(2.1$-fold, $p<0.05)<$ collagen IV (8.8-fold, $p<0.01)$.

Once the ability to regenerate the basement membrane was determined, we then assessed the expression of proteins crucial for superior qualitative healing, such as reduced scarring. The ADSC s on the gene-activated scaffold demonstrated a significantly $(p<0.05)$ reduced expression of the scar-associated contractile protein $\alpha$-SMA. The $\alpha$-SMA expression in the ADSCs was lower by $50 \%$ relative to the gene-free scaffold group (Figure 4B). Lastly, having observed the reduced $\alpha$-SMA expression, we assessed the expression of the elastic matrix protein elastin. The ADSCs on the gene-activated scaffold demonstrated a relatively superior qualitative elastin expression through the deposition of mature fibrous network of elastin compared to the ADSCs on the gene-free scaffold (Figure 4B). 

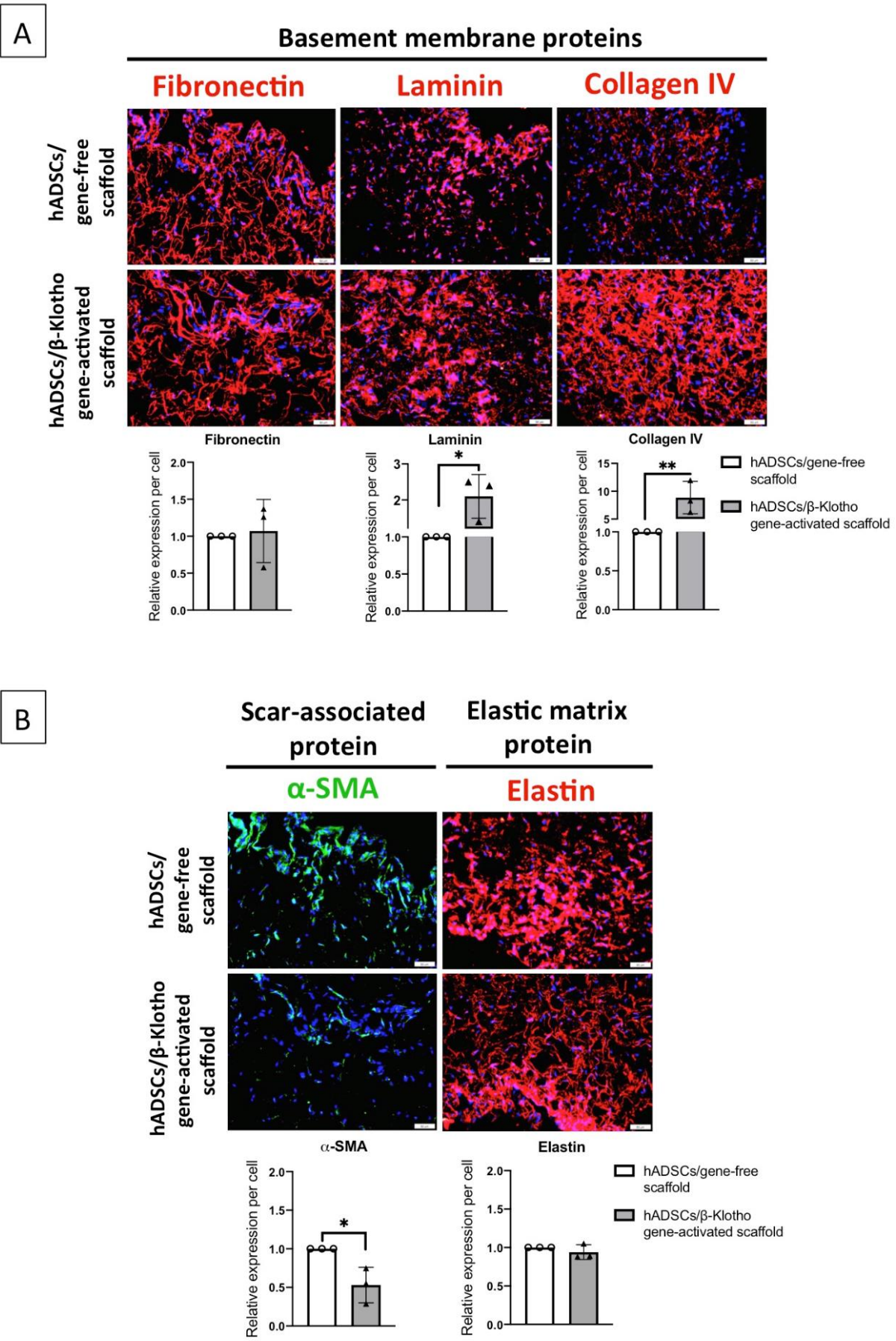

Figure 4. Deposition of pro-wound healing matrix proteins by the ADSCs in the gene-activated scaffold on day 14. (A) The ADSCs in the gene-activated scaffold demonstrated significant regeneration of the basement membrane compared to the ADSCs in the gene-free scaffold. The ADSCs predominantly deposited a relatively mature network of collagen IV proteins, followed by laminin and fibronectin. (B) The ADSCs in the gene-activated scaffold also expressed 2-fold lower of the $\alpha$-SMA protein compared to the ADSCs in the gene-free scaffold. In conjunction with basement membrane regeneration, the ADSCs in the gene-activated scaffold deposited qualitatively better elastin matrix. All the images were captured through $20 \times$ objective using an IX73 Olympus microscope. ** and * indicates $p<0.01$ and $p<0.05$ respectively. Scale bar $50 \mu \mathrm{m}$. Data represents mean \pm standard deviation $(n=3)$. $\alpha$-SMA and fibronectin was double-immunostained. 


\section{Discussion}

This study aimed to investigate the functional impact of an anti-aging $\beta$-Klotho geneactivated scaffold on human ADSCs for enhanced wound healing applications. Overall, we found that the gene-activated scaffold offers controlled activation of ADSCs' regenerative abilities as depicted in Figure 5. Specifically, the gene-activated scaffold transiently enhanced ADSCs' stemness through the activation of transcription factor Oct- 4 . The gene-activated scaffold also promoted early activation of the anti-fibrotic gene TGF- $\beta 3$, a crucial factor for controlled healing with reduced scarring. Furthermore, the activated ADSCs temporally controlled endothelial angiogenesis and supported dermal fibroblasts healing through paracrine signaling. Towards maturation, the ADSCs also controlled the activation of pro-fibrotic response in the dermal fibroblasts. Meanwhile, the ADSCs on the gene-activated scaffold effectively regenerated the dermal basement membrane by enhancing laminin and collagen IV deposition. This response was further associated with reduced scar-associated $\alpha$-SMA protein expression and improved qualitative elastin matrix deposition. Our study collectively determined that the $\beta$-Klotho gene-activated scaffold possesses tremendous potential for wound healing and could advance stem cell-based therapy for rejuvenative healing applications.

\section{Summary:}

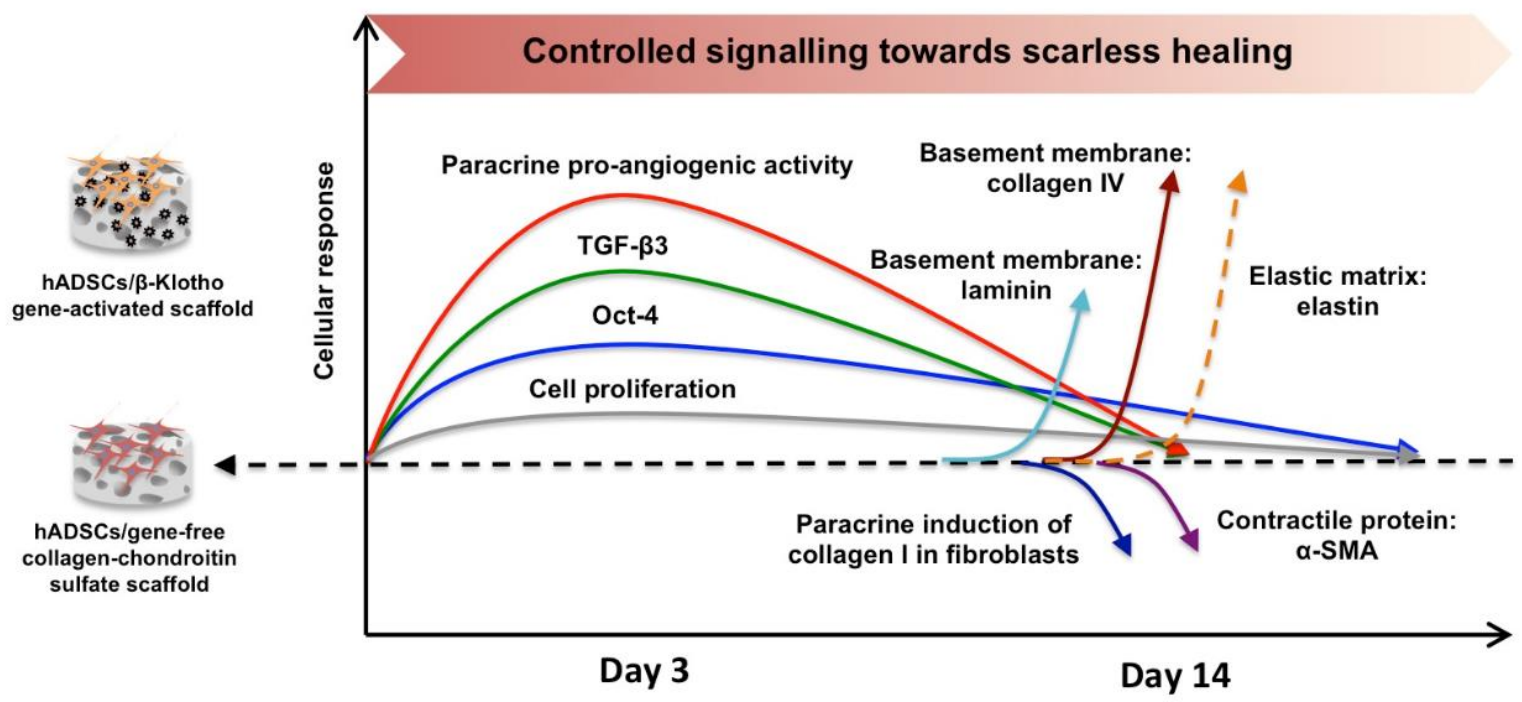

Figure 5. A schematic of the functional impact of $\beta$-Klotho gene-activated scaffold on human ADSCs for wound healing applications. The key findings of this study are the (1) transient enhancement of stem cell pluripotency and anti-fibrotic response, (2) improved paracrine control towards angiogenesis, and pro-fibrotic collagen remodeling in dermal fibroblasts, and ultimately, (3) increased maturation of the basement membrane with control over scar-associated proteins' expression. Dotted lines for elastin matrix imply improved qualitative deposition.

In wound healing strategies, plasmid-based gene therapy is applied to transiently enhance cellular responses until wound repair is complete [37]. Our gene-activated scaffold also shows that the therapeutic $\beta$-Klotho gene is transiently regulated over 14 days. The significantly enhanced (170-fold) expression of the $\beta$-Klotho mRNA at day 3 could be attributed to the immediate-early CMV promoter that is known to enhance transcriptional activation of the encoded transgene [38]. However, in the MSCs, the CMV could undergo DNA methylation or histone deacetylation that can reduce the transgene expression [39]. Moreover, the plasmids generally are non-replicating episomes, limiting the transfer of transgene to dividing cells, causing a decline in the transgene expression over time [40]. The presence of heterochromatic markers originating from the bacterial sequences of the 
plasmid could further repress transgene expression [41], overall contributing to a transient gene expression.

One of the avenues pursued for the treatment of hard-to-heal wounds is the application of cell-seeded bioactive scaffolds. One reason is their ability to promote rapid wound repair. Metabolically active cells in the graft secrete paracrine factors and undergo differentiation, orchestrating the complex signaling events in the wound environment [42]. Stem cells, in particular, have a unique ability to sense external stimuli and modulate their response to restore homeostasis [43]. However, stem cells lose their stemness when they are expanded in vitro to generate large cell numbers for the graft. Our study shows that the stemness can be transiently enhanced using a gene-activated scaffold carrying an anti-aging gene $\beta$-Klotho. Specifically, we noted that the anti-aging gene-activated scaffold enhanced the expression of the stemness gene Oct- 4 in the ADSCs. The Oct- 4 is one of the key transcriptional factors in embryonic stem cells and is essential for controlled embryonic development [44]. In the ADSCs, the activation of the Oct-4 gene can promote their proliferation and differentiation potential [45]. Thus, the increased expression of Oct-4 may facilitate rapid differentiation of the ADSCs on the gene-activated scaffold into host cells and aid in the healing process.

Having observed the activation of Oct-4 gene in the ADSCs, we then assessed the angiogenic potency of the ADSCs. Angiogenesis is crucial for efficient integration of the graft with the host tissue [46]. Cells in the graft trigger angiogenesis through the secretion of paracrine factors. Angiogenesis is also a crucial event for granulation tissue development and its activity diminishes as the granulation tissue mature [47]. This programmed limitation of the angiogenic activity at the healing's later stages is essential for controlling scarring and hypergranulation that can impede re-epithelialization [48]. Our finding also shows that the ADSCs on the gene-activated scaffold can enhance endothelial sprouting and control their growth through paracrine signaling. Additionally, the significant increases in the endothelial cells' metabolic activity and sprouting in response to day $3 \mathrm{CM}$ demonstrate the potential of the ADSCs-laden gene-activated scaffold to integrate with the host tissue rapidly. Moreover, the use of stem cells CM is a commonly adopted cell-free approach to enhance quality wound healing [49]. As a limitation, we acknowledge that adult dermal endothelial cells would serve a better cell model for studying angiogenesis; however to maintain consistency with our previous studies and the HUVECs being widely accepted as the "gold-standard" cell candidate [50], we adopted the HUVECs angiogenesis assay.

An increase in fibroblasts' remodeling activity is a general feature of granulation tissue maturation [51]. During this stage, collagen III matrix is gradually replaced by stronger collagen I fibers [51]. Collagen fibers then promote wound contraction [52], and wound contraction is indispensable for complete wound closure [53]. However, an aggressive sustained increase in collagen I deposition can increase scar formation [54]. Controlling scarring is crucial as it can inhibit the development of other skin appendages such as hair follicles, sebaceous glands, and sweat glands, for example, in burn wounds [54]. Our finding demonstrates that the aged (day 14) CM from the gene-activated scaffold group could control the expression of pro-fibrotic collagen I in the adult dermal fibroblasts. This controlled effect towards the fibroblasts occurred without further influence towards the fibroblast's migration or their anti-fibrotic collagen III expression relative to the gene-free scaffold group. Therefore, we suggest that the ADSCs-laden gene-activated scaffold may offer better control in limiting scarring in vivo through controlled collagen I expression. Li et al., have also shown that the ADSCs CM can significantly reduce collagen I expression in fibroblasts derived from hypertrophic scars [55]. Another study by Wang et al., demonstrated similar reduction in collagen I expression in keloid-derived fibroblasts [56], collectively demonstrating the anti-fibrotic potential of the ADSCs' CM.

One of the significant findings that we noted with the application of the $\beta$-Klotho gene-activated scaffold is the enhanced regeneration of basement membrane in the ADSCs. The regeneration of the basement membrane is essential for blood vessel maturation and complete re-epithelialization $[57,58]$. Importantly, the trend in which the proteins laminin 
(2.1-fold) and collagen IV (8.8-fold) are upregulated further indicates increased maturation of the basement membrane in the gene-activated scaffold group [59]. Besides acting as an anti-aging factor [60], the beta klotho functions to enhance sensitiveness to fibroblast growth factor (FGF) by FGF receptors [61]. Additionally, increase in FGF signaling has been found to promote basement membrane maturation through the deposition of laminin and collagen IV [62]. Therefore, considering beta klotho's role as a co-receptor of FGF, the increased basement maturation in the gene-activated scaffold group is potentially mediated by increase in ADSCs' FGF signaling.

The basement membrane component remarkably upregulated in the gene-activated scaffold group is the collagen IV protein. The collagen IV protein represents $50 \%$ of all basement membrane [63] and provides structural stability to the basement membrane [59]. However, aging significantly reduces collagen IV expression in the dermal-epidermal junction [58,64] and the lack of collagen IV can promote scar pathogenesis [65]. Thus, our results suggest that the increased basement membrane regenerative potency of the ADSCsladen gene-activated scaffold can significantly aid in enhanced healing in aged patients. Other studies have also shown that the adipose tissue-derived ECM possess tremendous therapeutic potential for skin repair [66]. Furthermore, tissue-engineered grafts rich in laminin and collagen IV is also of interest for respiratory epithelium repair [67].

In addition to the pro-fibrotic control towards the fibroblasts, our study further shows that the ADSCs in the gene-activated scaffold also express a 2-fold lower expression of the scar-associated protein $\alpha$-SMA [68]. Although we did not evaluate its impact in vivo, the reduction in local $\alpha$-SMA expression is crucial for improved qualitative healing [69]. Using fibrotic agents such as bleomycin [70] could be one way to evaluate better the anti-fibrotic properties of the ADSCs/gene-activated scaffold construct in vitro; however, our focus was to establish the provisional therapeutic potential of the construct.

Another indicator that the ADSCs-laden gene-activated scaffold may improve qualitative healing is the deposition of fibrous elastin matrix instead of patchy extracellular secretions in the gene-free scaffold group. Elastin deposition is one of the main activities that drive fetal scarless wound healing [71]. However, adult skins lack the deposition of elastin [71]. As such, tropoelastin, a precursor of elastin, is often incorporated into biomaterial scaffolds to control scarring in wound healing [72]. Taken together, our findings imply that the ADSCs / $\beta$-Klotho gene-activated scaffold construct may confer a strong anti-fibrotic response in vivo.

\section{Materials and Methods}

\subsection{Preparation of Gene-Activated Scaffold}

The gene-activated scaffold was developed using a 2-step process. Firstly, solid porous collagen-chondroitin sulfate scaffolds were fabricated by freeze-drying slurry of bovine tendon type 1 collagen and chondroitin-6-sulfate derived from shark cartilage (Sigma, UK). An optimized freeze-drying process designed to create uniform pores were used to produce the scaffolds [73]. Based on our published protocol [74], the freezedried scaffolds were then dehydrothermally (DHT) treated at $105^{\circ} \mathrm{C}$ under vacuum for sterilization and mechanical improvement. The sterilized scaffolds were then chemically cross-linked with 14 mM N-(3-Dimethylaminopropyl)-N'-ethylcarbodiimide hydrochloride and $5.5 \mathrm{mM}$ N-Hydroxysuccinimide (2.5 molar ratio of EDC/NHS) (Sigma, UK) solution to further improve the mechanical stability [75]. The cross-linked scaffolds were then washed with PBS (Gibco, Paisley, UK) to remove residual chemicals. Once the scaffolds were ready, polyplexes at an N/P10 ratio (nitrogen to phosphate ratio) were prepared by mixing a predetermined volume of branched polyethyleneimine (PEI) solution with plasmid DNA ( $p D N A$ ) encoding for the human beta-Klotho gene ( $\beta$-Klotho), obtained from SinoBiological, Beijing, China. The N/P10 ratio was chosen based on our previous studies that found that polyplexes formulated at an N/P 10 ratio could effectively form small, stable cationic nanoparticles with plasmids as large as GLuc $(5.76 \mathrm{~kb})$ [21,23]. Prior to use, the plasmids were diluted in endotoxin free water to obtain a working concentration 
of $0.5 \mu \mathrm{g} / \mu \mathrm{L}$. The plasmid contains human enhanced immediate-early cytomegalovirus (CMV3) promoter to promote high-level stable and transient expression of the encoded gene in mammalian cells.

The plasmid/PEI mix was allowed to settle for $30 \mathrm{~min}$ to self-assemble into polyplex nanoparticles. The nanoparticles were then soak-loaded onto the scaffolds by pipetting equal volumes of the polyplex solution per side of the scaffold. A total of $2 \mu \mathrm{g}$ pDNA was used per scaffold to develop the gene-activated scaffold.

\subsection{Cell Seeding on $\beta$-Klotho Gene-Activated Scaffold}

Human ADSCs (iXCells Biotechnologies, San Diego, CA, USA) were expanded to passage 4 in the ADSCs growth medium (Cat no. MD0003) supplied by the company. A total of $5 \times 10^{5}$ ADSCs $\left(2.5 \times 10^{5}\right.$ per side) were then seeded per gene-free scaffold (control, $n=3$ ) or gene-activated scaffold (test, $n=3$ ). After letting the cells settle for about $20 \mathrm{~min}$, $2 \mathrm{~mL}$ of transfection media OptiMEM (Gibco, UK) was added, and the cellularized scaffolds were incubated at $37^{\circ} \mathrm{C}$ for $24 \mathrm{~h}$. After the $24 \mathrm{~h}$ incubation, the cellularized gene-free or gene-activated scaffolds were transferred into new 12-well plates, and fed with $2 \mathrm{~mL}$ of ADSCs growth medium. Media change was then performed every 3-4 days until day 14 by collecting $1 \mathrm{~mL}$ of the conditioned media $(\mathrm{CM})$ and replacing it with equal volume of fresh media. All $\mathrm{CM}$ were stored at $-80^{\circ} \mathrm{C}$ until analysis.

\section{3. qRT-PCR Analyses to Determine $\beta$-Klotho Gene Overexpression and Activation of Functional Genes}

In order to determine transient regulation of the target genes, cells were harvested at days 3 (early) and 14 (late) post-seeding on the gene-free or gene-activated scaffolds. The cells were first lysed using the Qiazol lysis reagent (Qiagen, Germantown, MD, USA). Chloroform was then added to separate the cell lysate into protein, DNA and RNA phases. Using the RNeasy Kit (Qiagen, Manchester, UK), the RNA was extracted, and their quality and quantity were determined using a Multiskan Go plate reader (Thermo Scientific, UK) with the absorbance set at $260 \mathrm{~nm}$. Genomic DNA was then removed by mixing the RNA with a genomic DNA wipeout buffer (Qiagen, Manchester, UK) and heating to $42{ }^{\circ} \mathrm{C}$ for $2 \mathrm{~min}$. Subsequently, reverse transcription was performed to prepare the cDNA. Duplicates of cDNA per replicate $(n=3)$ were loaded into the qRT-PCR plates and then the assay was run using the primers listed in Table 1 . Fold change in mRNA expression relative to the cells on gene-free scaffold was calculated using the $2^{-\Delta \Delta C T}$ method from averages of three replicates per group. Human GAPDH (Hs_GAPDH_1_SG, Cat. No. QT00079247) was used as the housekeeping gene.

Table 1. List of functional genes associated with ADSCs' growth and development.

\begin{tabular}{|c|c|c|}
\hline Function & Primer (Catalog No.) & Encoded Gene \\
\hline \multirow{2}{*}{ Activation and proliferation } & $\begin{array}{c}\text { Hs_KLB_4_SG } \\
\text { (QT02454977) }\end{array}$ & Beta Klotho ( $\beta$-Klotho) \\
\hline & $\begin{array}{l}\text { Hs_MKI67_1_SG } \\
\text { (QT00014203) }\end{array}$ & Marker of proliferation (Ki-67) \\
\hline \multirow{3}{*}{ Stemness or pluripotency promoters } & $\begin{array}{c}\begin{array}{c}\text { Hs_POU5 F1_1_SG } \\
\text { (QT00210840) }\end{array} \\
\text { (QT) }\end{array}$ & Octamer-binding transcription factor 4 (Oct- 4$)$ \\
\hline & $\begin{array}{c}\text { Hs_NANOG_1_SG } \\
\text { (QT01025850) }\end{array}$ & Homeobox protein (Nanog) \\
\hline & $\begin{array}{c}\text { Hs_SOX2_1_SG } \\
\text { (QT00237601) }\end{array}$ & Sex determining region Y-box 2 (Sox-2) \\
\hline \multirow{2}{*}{ Wound healing regulators } & $\begin{array}{c}\text { Hs_TGFB3_1_SG } \\
\text { (QT00001302) }\end{array}$ & Transforming growth factor beta 3 (TGF- $\beta 3$ ) \\
\hline & $\begin{array}{l}\text { Hs_TGFB1_1_SG } \\
\text { (QT00000728) }\end{array}$ & Transforming growth factor beta 1 (TGF- $\beta 1$ ) \\
\hline
\end{tabular}




\subsection{Bioactivity Analyses of Secreted Factors from the ADSCs on $\beta$-Klotho Gene-Activated Scaffold 4.4.1. Pro-Angiogenic Bioactivity Analyses}

Next, we studied the paracrine potency of the ADSCs on $\beta$-Klotho gene-activated scaffold. As angiogenesis is crucial for graft integration, we first studied the angiogenic impact of CM on human umbilical vein endothelial cells (HUVECs). The assessment was conducted in two stages. Firstly, a temporal effect of the CM on the HUVECs was determined by assaying the metabolic activity in the HUVECs incubated with the CM collected from all the time points-day 3, 7, 10, and 14. Briefly, $1 \times 10^{4}$ HUVECs/well in a 96-well plate was incubated in the CM for $24 \mathrm{~h}$ and the response was assayed using the standard MTS assay. Subsequently, CM from days 3 and 14 were used for Matrigel assay. For the Matrigel assay, the HUVECs were seeded at a density of $3 \times 10^{4}$ cells/well of a 48 -well plate pre-coated with $120 \mu \mathrm{L}$ of Matrigel for $30 \mathrm{~min}$ at $37^{\circ} \mathrm{C}$. At $6 \mathrm{~h}$ post-exposure to $\mathrm{CM}$, images of the morphological changes in the endothelial cells were captured using an inverted microscope (IX73, Olympus, Japan) and the mean number of tubules and branching points were counted using the ImageJ software (ImageJ, National Institutes of Health, Bethesda, MD, USA).

\subsubsection{Dermal Fibroblasts Healing and Maturation Analyses}

After the angiogenesis assay, we investigated the CM's potency for dermal healing by employing a scratch assay of human adult dermal fibroblasts (iXcells, Cat no. $10 \mathrm{HU}-014$ ). For this study, we specifically chose the aged CM from day 14 to study its influence on fibroblasts' wound closure during maturation. A total of $1 \times 10^{4}$ cells/well in a 96-well plate were seeded and incubated overnight in the fibroblast growth medium. The next day, a wound was created on the monolayer by horizontally scratching a $200 \mathrm{uL}$ pipette tip across the well. The monolayer was then rinsed with PBS to remove any debris and fed with the CM. Wound closure was recorded between 12-16 h after the scratch. Immunostaining was used to study the expression of pro-fibrotic collagen I (1:100, Novusbio, UK) and anti-fibrotic collagen III (1:100, Novusbio, UK) in the fibroblasts. The fibroblasts were counterstained with rhodamine (1:800, Abcam, UK) for F-actin imaging. Immunostaining was performed as described in Section 4.5, with the exception of tissue processing and deparafinization. Both HUVECs and the fibroblasts were used at passage 4 .

\subsection{Immunofluorescence Imaging of Extracellular Matrix Proteins}

After 14 days of culture, the cellularized gene-free or gene-activated scaffolds were harvested for detection of matrix deposition using immunofluorescence. The processing of the samples was performed as described previously. Briefly, the scaffolds were first washed with PBS and fixed in 10\% neutral buffered formalin for $20 \mathrm{~min}$. The fixed samples were then processed using the standard protocol for paraffinization. The blocks were then cut into $7-\mu \mathrm{m}$ thick slices and collected on charged slides. The sections were then deparaffinized using xylene followed by rehydration of the section with decreasing gradients of ethanol. Subsequently, the cells were permeabilized with $0.2 \%$ Tween ${ }^{\circledR} 20$ (Sigma-Aldrich, France) solution in PBS for $30 \mathrm{~min}(10 \mathrm{~min}$ wash $\times 3$ ) and blocked using 10\% NGS (Normal Goat Serum, Invitrogen, Rockford, IL, USA)/5\% BSA/0.3 M Glycine (prepared in permeabilizing solution) for $1 \mathrm{~h}$. After blocking, the slides were rinsed in PBS and then incubated at $4{ }^{\circ} \mathrm{C}$ overnight with the antibodies to target matrix proteins listed in Table 2.

The next day, the slides were rinsed in PBS thrice for 2-3 min each to remove any unbound primary antibodies. Subsequently, the slides were incubated in either Alexa 488-conjugated goat anti-mouse IgG (A32723, Invitrogen, UK) or Alexa 594-conjugated goat anti-rabbit IgG (A11012, Invitrogen, UK) at 1:800 dilution at room temperature for $1 \mathrm{~h}$ in the dark. The rinsing step was performed as before and counterstained for nuclei using the mounting medium with DAPI (ab104139, Abcam, UK). The slides were then imaged using fluorescence microscope (Olympus BX43, Japan) at 20× objective. Samples incubated with only secondary antibodies were used as controls. 
Table 2. List of primary antibodies to extracellular matrix proteins involved in wound healing.

\begin{tabular}{ccc}
\hline Functional Roles & $\begin{array}{c}\text { Primary Antibodies } \\
\text { (Catalog No.) }\end{array}$ & $\begin{array}{c}\text { Dilutions in 1\% BSA } \\
\text { Solution }\end{array}$ \\
\hline Basement membrane proteins & $\begin{array}{c}\text { Fibronectin } \\
(\text { ab2413, Abcam, UK) } \\
\text { Laminin } \\
\text { (ab11575, Abcam, UK) } \\
\text { Collagen IV } \\
\text { (ab6586, Abcam, UK) }\end{array}$ & $1: 200$ \\
\hline Scar-associated contractile protein & $\begin{array}{c}\text { Alpha-smooth muscle actin } \\
\text { (ab7817, Abcam, UK) }\end{array}$ & $1: 200$ \\
\hline Elastic matrix protein & $\begin{array}{c}\text { Elastin } \\
\text { (ab21607, Abcam, UK) }\end{array}$ & $1: 100$ \\
\hline
\end{tabular}

Image Quantification

ImageJ software (ImageJ, NIH, MD, USA) was used to semi-quantitatively determine the amount of expressed proteins. For each marker, a constant threshold value was first determined through preliminary imaging of various sections. Using the set threshold value, integrated density (stained area $\times$ mean gray value) of the images was determined and then normalized to the number of cells (DAPI counting) to give a final mean fluorescence density per cell. An average was quantified from 8-10 random images per replicate, with a minimum of three replicates per group. The averages obtained from the three replicates/group were then used for measuring relative expression between the groups.

\subsection{Statistical Analysis}

All results are expressed as mean \pm standard deviation. Unpaired, two-tailed t-test was generally used to calculate the statistical significance between groups, where $p<0.05$ was considered to be significant.

\section{Conclusions}

This study showed that the anti-aging $\beta$-Klotho gene-activated scaffold offers controlled activation of the regenerative capacity of ADSCs. The key findings of this study are the (1) transient enhancement of stem cell pluripotency and anti-fibrotic response, (2) improved paracrine control towards angiogenesis, and pro-fibrotic collagen remodeling in dermal fibroblasts, and ultimately, (3) increased maturation of the basement membrane with control over scar-associated proteins' expression. Conclusively, these results suggest that the ADSCs-laden $\beta$-Klotho gene-activated scaffold may possess great potential a treating a wide range of dermal wounds.

Author Contributions: Conceptualization, A.L.L. and M.B.K.; methodology, A.L.L. and M.B.K.; software, A.L.L.; validation, A.L.L., F.J.O. and M.B.K.; formal analysis, A.L.L.; investigation, A.L.L.; resources, A.L.L., F.J.O. and M.B.K.; data curation, A.L.L. and M.B.K.; writing-original draft preparation, A.L.L.; writing-review and editing, A.L.L., F.J.O. and M.B.K.; visualization, A.L.L.; supervision, F.J.O. and M.B.K.; project administration, M.B.K.; funding acquisition, F.J.O. and M.B.K. All authors have read and agreed to the published version of the manuscript.

Funding: This work was funded by RCSI Bahrain Internal Research Grant BR00090. The APC was funded by RCSI Bahrain. F.O.B acknowledges funding from Science Foundation Ireland under the M-ERA.NET program (Dressing4 Scars (16/M-ERA/3420) and the Advanced Materials and BioEngineering Research Centre (AMBER; grants 12/RC/2278 and 12/RC/2278_P2) in addition to EU BlueHuman Interreg Atlantic Area Project (grant EAPA_151/2016).

Institutional Review Board Statement: Not applicable.

Informed Consent Statement: Not applicable. 
Data Availability Statement: The data presented in this study are available on request from the corresponding author. The data are not publicly available due to privacy or ethical restrictions.

Conflicts of Interest: The authors declare that no conflict of interest exists.

\section{References}

1. Laiva, A.L.; O’Brien, F.J.; Keogh, M.B. Innovations in gene and growth factor delivery systems for diabetic wound healing. J. Tissue Eng. Regen. Med. 2018, 12, e296-e312. [CrossRef] [PubMed]

2. Makrantonaki, E.; Wlaschek, M.; Scharffetter-Kochanek, K. Pathogenesis of wound healing disorders in the elderly. JDDG J. Dtsch. Dermatol. Ges. 2017, 15, 255-275. [CrossRef] [PubMed]

3. Ganguly, P.; El-Jawhari, J.J.; Burska, A.N.; Ponchel, F.; Giannoudis, P.V.; Jones, E.A. The analysis of in vivo aging in human bone marrow mesenchymal stromal cells using colony-forming unit-fibroblast assay and the CD45lowCD271+ phenotype. Stem Cells Int. 2019, 2019, 5197983. [CrossRef]

4. Westerweel, P.E.; Teraa, M.; Rafii, S.; Jaspers, J.E.; White, I.A.; Hooper, A.T.; Verhaar, M.C. Impaired endothelial progenitor cell mobilization and dysfunctional bone marrow stroma in diabetes mellitus. PLoS ONE 2013, 8, e60357. [CrossRef]

5. Murray, R.Z.; West, Z.E.; Cowin, A.J.; Farrugia, B.L. Development and use of biomaterials as wound healing therapies. Burn. Trauma 2019, 7. [CrossRef] [PubMed]

6. Ebrahimian, T.G.; Pouzoulet, F.; Squiban, C.; Buard, V.; André, M.; Cousin, B.; Tamarat, R. Cell therapy based on adipose tissue-derived stromal cells promotes physiological and pathological wound healing. Arterioscler. Thromb. Vasc. Biol. 2009, 29, 503-510. [CrossRef]

7. $\mathrm{Wu}, \mathrm{Y}$;; Chen, L.; Scott, P.G.; Tredget, E.E. Mesenchymal stem cells enhance wound healing through differentiation and angiogenesis. Stem Cells 2007, 25, 2648-2659. [CrossRef] [PubMed]

8. Foubert, P.; Gonzalez, A.D.; Teodosescu, S.; Berard, F.; Doyle-Eisele, M.; Yekkala, K.; Fraser, J.K. Adipose-Derived Regenerative Cell Therapy for Burn Wound Healing: A Comparison of Two Delivery Methods. Adv. Wound Care 2016, 5, 288-298. [CrossRef] [PubMed]

9. Assi, R.; Foster, T.R.; He, H.; Stamati, K.; Bai, H.; Huang, Y.; Dardik, A. Delivery of mesenchymal stem cells in biomimetic engineered scaffolds promotes healing of diabetic ulcers. Regen. Med. 2016, 11, 245-260. [CrossRef] [PubMed]

10. Jiang, Y.; Chen, B.; Liu, Y.; Zhufu, Z.; Yan, X.; Hou, X.; Tan, Q. Effect of collagen scaffold with adipose-derived stromal vascular fraction cells on diabetic wound healing: A study in a diabetic porcine model. Tissue Eng. Regen. Med. 2013, 10, 192-199. [CrossRef]

11. Falanga, V.; Sabolinski, M. A bilayered living skin construct (APLIGRAF ${ }^{\circledR}$ ) accelerates complete closure of hard-to-heal venous ulcers. Wound Repair Regen. 1999, 7, 201-207. [CrossRef]

12. Hart, C.E.; Loewen-Rodriguez, A.; Lessem, J. Dermagraft: Use in the treatment of chronic wounds. Adv. Wound Care. 2012, 1, 138-141. [CrossRef] [PubMed]

13. Dinh, T.L.; Veves, A. The efficacy of Apligraf in the treatment of diabetic foot ulcers. Plast. Reconstr. Surg. 2006, 117, 152S-157S. [CrossRef] [PubMed]

14. Eaglstein, W.H.; Falanga, V. Tissue engineering and the development of Apligraf ${ }^{\circledR}$, a human skin equivalent. Clin. Ther. 1997, 19, 894-905. [CrossRef]

15. Jiang, T.; Xu, G.; Wang, Q.; Yang, L.; Zheng, L.; Zhao, J.; Zhang, X. In vitro expansion impaired the stemness of early passage mesenchymal stem cells for treatment of cartilage defects. Cell Death Dis 2017, 8, e2851. [CrossRef] [PubMed]

16. Liu, J.; Ding, Y.; Liu, Z.; Liang, X. Senescence in Mesenchymal Stem Cells: Functional Alterations, Molecular Mechanisms, and Rejuvenation Strategies. Front. Cell Dev. Biol. 2020, 8, 258. [CrossRef] [PubMed]

17. Wang, W.; Xu, X.; Li, Z.; Lendlein, A.; Ma, N. Genetic engineering of mesenchymal stem cells by non-viral gene delivery. Clin. Hemorheol. Microcirc. 2014, 58, 19-48. [CrossRef]

18. Deveza, L.; Choi, J.; Lee, J.; Huang, N.; Cooke, J.; Yang, F. Polymer-DNA Nanoparticle-Induced CXCR4 Overexpression Improves Stem Cell Engraftment and Tissue Regeneration in a Mouse Hindlimb Ischemia Model. Theranostics 2016, 6, 1176-1189. [CrossRef] [PubMed]

19. O’Brien, F.J. Biomaterials \& scaffolds for tissue engineering. Mater. Today 2011, 14, 88-95.

20. Yannas, I.; Tzeranis, D.; Harley, B.; So, P. Biologically active collagen-based scaffolds: Advances in processing and characterization. Philos. Trans. R. Soc. A Math. Phys. Eng. Sci. 2010, 368, 2123-2139. [CrossRef]

21. Laiva, A.L.; Raftery, R.M.; Keogh, M.B.; O’Brien, F.J. Pro-angiogenic impact of SDF-1 $\alpha$ gene-activated collagen-based scaffolds in stem cell driven angiogenesis. Int. J. Pharm. 2018, 544, 372-379. [CrossRef] [PubMed]

22. Lackington, W.A.; Raftery, R.M.; O’Brien, F.J. In vitro efficacy of a gene-activated nerve guidance conduit incorporating non-viral PEI-pDNA nanoparticles carrying genes encoding for NGF, GDNF and c-Jun. Acta Biomater. 2018, 75, 115-128. [CrossRef]

23. Tierney, E.G.; Duffy, G.P.; Hibbitts, A.J.; Cryan, S.A.; O’Brien, F.J. The development of non-viral gene-activated matrices for bone regeneration using polyethyleneimine (PEI) and collagen-based scaffolds. J. Control. Release 2012, 158, 304-311. [CrossRef] [PubMed]

24. Laiva, A.L.; O'Brien, F.J.; Keogh, M.B. SDF-1 $\alpha$ gene-activated collagen scaffold drives functional differentiation of human Schwann cells for wound healing applications. Biotechnol. Bioeng. 2021, 118, 725-736. [CrossRef] [PubMed] 
25. Laiva, A.L.; O'Brien, F.J.; Keogh, M.B. SDF-1 $\alpha$ gene-activated collagen scaffold enhances provasculogenic response in a coculture of human endothelial cells with human adipose-derived stromal cells. J. Mater. Sci. Mater. Med. 2021, 32, 26. [CrossRef]

26. Bonadio, J.; Smiley, E.; Patil, P.; Goldstein, S. Localized, direct plasmid gene delivery in vivo: Prolonged therapy results in reproducible tissue regeneration. Nat Med 1999, 5, 753-759. [CrossRef] [PubMed]

27. Kolakshyapati, P.; Li, X.; Chen, C.; Zhang, M.; Tan, W.; Ma, L.; Gao, C. Gene-activated matrix/bone marrow-derived mesenchymal stem cells constructs regenerate sweat glands-like structure in vivo. Sci. Rep. 2017, 7, 17630. [CrossRef]

28. Marolt, D.; Knezevic, M.; Vunjak-Novakovic, G. Bone tissue engineering with human stem cells. Stem Cell Res. Ther. 2010, 1, 10. [CrossRef]

29. Holm, J.S.; Toyserkani, N.M.; Sorensen, J.A. Adipose-derived stem cells for treatment of chronic ulcers: Current status. Stem Cell Res. Ther. 2018, 9, 142. [CrossRef]

30. Laiva, A.L.; O’Brien, F.J.; Keogh, M.B. SDF-1 $\alpha$ Gene-Activated Collagen Scaffold Restores Pro-Angiogenic Wound Healing Features in Human Diabetic Adipose-Derived Stem Cells. Biomedicines 2021, 9, 160. [CrossRef] [PubMed]

31. Wan Safwani, W.K.; Makpol, S.; Sathapan, S.; Chua, K.H. The changes of stemness biomarkers expression in human adiposederived stem cells during long-term manipulation. Biotechnol. Appl. Biochem. 2011, 58, 261-270. [CrossRef] [PubMed]

32. Suku, M.; Laiva, A.L.; O’Brien, F.J.; Keogh, M.B. Anti-Ageing Protein $\beta$-Klotho Rejuvenates Diabetic Stem Cells for Improved Gene-Activated Scaffold Based Wound Healing. J. Pers. Med. 2020, 11, 4. [CrossRef]

33. Ullah, M.; Sun, Z. Klotho Deficiency Accelerates Stem Cells Aging by Impairing Telomerase Activity. J. Gerontol. A Biol. Sci. Med. Sci. 2019, 74, 1396-1407. [CrossRef] [PubMed]

34. Fan, J.; Sun, Z. The Antiaging Gene Klotho Regulates Proliferation and Differentiation of Adipose-Derived Stem Cells. Stem Cells 2016, 34, 1615-1625. [CrossRef] [PubMed]

35. Fan, F.; Li, Y.; Liu, Y.; Shao, L.; Yu, J.; Li, Z. Overexpression of klotho in adipose-derived stem cells protects against UVB-induced photoaging in co-cultured human fibroblasts. Mol. Med. Rep. 2018, 18, 5473-5480. [CrossRef] [PubMed]

36. Zhang, F.; Wan, X.; Cao, Y.Z.; Sun, D.; Cao, C.C. Klotho gene-modified BMSCs showed elevated antifibrotic effects by inhibiting the Wnt/ $\beta$-catenin pathway in kidneys after acute injury. Cell Biol. Int. 2018, 42, 1670-1679. [CrossRef]

37. Branski, L.; Pereira, C.; Herndon, D.; Jeschke, M. Gene therapy in wound healing: Present status and future directions. Gene Ther. 2007, 14, 1-10. [CrossRef] [PubMed]

38. Radhakrishnan, P.; Basma, H.; Klinkebiel, D.; Christman, J.; Cheng, P.-W. Cell type-specific activation of the cytomegalovirus promoter by dimethylsulfoxide and 5-aza-2'-deoxycytidine. Int. J. Biochem. Cell Biol. 2008, 40, 1944-1955. [CrossRef] [PubMed]

39. Wen, S.; Zhang, H.; Li, Y.; Wang, N.; Zhang, W.; Yang, K.; Wu, N.; Chen, X.; Deng, F.; Liao, Z.; et al. Characterization of constitutive promoters for piggyBac transposon-mediated stable transgene expression in mesenchymal stem cells (MSCs). PLoS ONE 2014, 9, e94397. [CrossRef] [PubMed]

40. Hardee, C.L.; Arévalo-Soliz, L.M.; Hornstein, B.D.; Zechiedrich, L. Advances in non-viral DNA vectors for gene therapy. Genes 2017, 8, 65. [CrossRef]

41. Alhaji, S.Y.; Ngai, S.C.; Abdullah, S. Silencing of transgene expression in mammalian cells by DNA methylation and histone modifications in gene therapy perspective. Biotechnol. Genet. Eng. Rev. 2019, 35, 1-25. [CrossRef]

42. Shevchenko, R.V.; James, S.L.; James, S.E. A review of tissue-engineered skin bioconstructs available for skin reconstruction. J. R. Soc. Interface 2010, 7, 229-258. [CrossRef] [PubMed]

43. Ellison, D.D.; Suhail, Y.; Afzal, J.; Woo, L.; Kilic, O.; Spees, J.; Levchenko, A. Dynamic secretome of bone marrow-derived stromal cells reveals a cardioprotective biochemical cocktail. Proc. Natl. Acad. Sci. USA 2019, 116, 14374-14383.

44. Shi, G.; Jin, Y. Role of Oct4 in maintaining and regaining stem cell pluripotency. Stem Cell Res. Ther. 2010, 1, 39. [CrossRef] [PubMed]

45. Han, S.-M.; Han, S.-H.; Coh, Y.-R.; Jang, G.; Ra, J.C.; Kang, S.-K.; Lee, H.-W.; Youn, H.-Y. Enhanced proliferation and differentiation of Oct4-and Sox2-overexpressing human adipose tissue mesenchymal stem cells. Exp. Mol. Med. 2014, 46, e101. [CrossRef] [PubMed]

46. Perry, L.; Landau, S.; Flugelman, M.Y.; Levenberg, S. Genetically engineered human muscle transplant enhances murine host neovascularization and myogenesis. Commun. Biol. 2018, 1, 161. [CrossRef] [PubMed]

47. DiPietro, L.A. Angiogenesis and wound repair: When enough is enough. J. Leukoc. Biol. 2016, 100, 979-984. [CrossRef] [PubMed]

48. Kornhaber, R.; Jaeger, M.; Harats, M.; Aviv, U.; Zerach, A.; Haik, J. Treatment of hypergranulation tissue in burn wounds with topical steroid dressings: A case series. Int. Med. Case Rep. J. 2016, 9, 241-245. [CrossRef] [PubMed]

49. Joseph, A.; Baiju, I.; Bhat, I.A.; Pandey, S.; Bharti, M.; Verma, M.; Singh, A.P.; Ansari, M.M.; Chandra, V.; Saikumar, G.; et al. Mesenchymal stem cell-conditioned media: A novel alternative of stem cell therapy for quality wound healing. J. Cell. Physiol. 2020, 235, 5555-5569. [CrossRef]

50. Ni, C.-W.; Kumar, S.; Ankeny, C.J.; Jo, H. Development of immortalized mouse aortic endothelial cell lines. Vasc. Cell 2014, 6, 7. [CrossRef] [PubMed]

51. Reinke, J.; Sorg, H. Wound repair and regeneration. Eur. Surg. Res. 2012, 49, 35-43. [CrossRef] [PubMed]

52. Brauer, E.; Lippens, E.; Klein, O.; Nebrich, G.; Schreivogel, S.; Korus, G.; Duda, G.N.; Petersen, A. Collagen Fibrils Mechanically Contribute to Tissue Contraction in an In Vitro Wound Healing Scenario. Adv. Sci. 2019, 6, 1801780. [CrossRef]

53. Berry, D.P.; Harding, K.G.; Stanton, M.R.; Jasani, B.; Ehrlich, H.P. Human wound contraction: Collagen organization, fibroblasts, and myofibroblasts. Plast Reconstr. Surg. 1998, 102, 124-131. [CrossRef] 
54. Marshall, C.D.; Hu, M.S.; Leavitt, T.; Barnes, L.A.; Lorenz, H.P.; Longaker, M.T. Cutaneous Scarring: Basic Science, Current Treatments, and Future Directions. Adv. Wound Care 2018, 7, 29-45. [CrossRef] [PubMed]

55. Li, Y.; Zhang, W.; Gao, J.; Liu, J.; Wang, H.; Li, J.; Yang, X.; He, T.; Guan, H.; Zheng, Z.; et al. Adipose tissue-derived stem cells suppress hypertrophic scar fibrosis via the p38/MAPK signaling pathway. Stem Cell Res. Ther. 2016, 7, 102. [CrossRef] [PubMed]

56. Wang, X.; Ma, Y.; Gao, Z.; Yang, J. Human adipose-derived stem cells inhibit bioactivity of keloid fibroblasts. Stem Cell Res. Ther. 2018, 9, 40. [CrossRef]

57. Davis, G.E.; Senger, D.R. Endothelial extracellular matrix: Biosynthesis, remodeling, and functions during vascular morphogenesis and neovessel stabilization. Circ. Res. 2005, 97, 1093-1107. [CrossRef] [PubMed]

58. Fisher, G.; Rittié, L. Restoration of the basement membrane after wounding: A hallmark of young human skin altered with aging. J. Cell Commun. Signal. 2018, 12, 401-411. [CrossRef] [PubMed]

59. Hohenester, E.; Yurchenco, P.D. Laminins in basement membrane assembly. Cell Adhes. Migr. 2013, 7, 56-63. [CrossRef] [PubMed]

60. Xu, L.; Idrees, M.; Joo, M.-D.; Sidrat, T.; Wei, Y.; Song, S.-H.; Lee, K.-L.; Kong, I.-K. Constitutive Expression of TERT Enhances $\beta$-Klotho Expression and Improves Age-Related Deterioration in Early Bovine Embryos. Int. J. Mol. Sci. 2021, 22, 5327. [CrossRef] [PubMed]

61. Suzuki, M.; Uehara, Y.; Motomura-Matsuzaka, K.; Oki, J.; Koyama, Y.; Kimura, M.; Asada, M.; Komi-Kuramochi, A.; Oka, S.; Toru, T. $\beta$ Klotho is required for fibroblast growth factor (FGF) 21 signaling through FGF receptor (FGFR) 1c and FGFR3c. Mol. Endocrinol. 2008, 22, 1006-1014. [CrossRef]

62. Li, X.; Chen, Y.; Schéele, S.; Arman, E.; Haffner-Krausz, R.; Ekblom, P.; Lonai, P. Fibroblast growth factor signaling and basement membrane assembly are connected during epithelial morphogenesis of the embryoid body. J. Cell Biol. 2001, 153, 811-822. [CrossRef]

63. LeBleu, V.S.; MacDonald, B.; Kalluri, R. Structure and function of basement membranes. Exp. Biol. Med. 2007, 232, 1121-1129. [CrossRef]

64. Roig-Rosello, E.; Rousselle, P. The Human Epidermal Basement Membrane: A Shaped and Cell Instructive Platform That Aging Slowly Alters. Biomolecules 2020, 10, 1607. [CrossRef] [PubMed]

65. Yang, S.; Sun, Y.; Geng, Z.; Ma, K.; Sun, X.; Fu, X. Abnormalities in the basement membrane structure promote basal keratinocytes in the epidermis of hypertrophic scars to adopt a proliferative phenotype. Int. J. Mol. Med. 2016, 37, 1263-1273. [CrossRef] [PubMed]

66. Zhou, Z.; Chen, Y.; Chai, M.; Tao, R.; Lei, Y.; Jia, Y.; Shu, J.; Ren, J.; Li, G.; Wei, W. Adipose extracellular matrix promotes skin wound healing by inducing the differentiation of adipose-derived stem cells into fibroblasts. Int. J. Mol. Med. 2019, 43, 890-900. [CrossRef]

67. Hamilton, N.J.; Lee, D.D.H.; Gowers, K.H.; Butler, C.R.; Maughan, E.F.; Jevans, B.; Orr, J.C.; McCann, C.J.; Burns, A.J.; MacNeil, S.; et al. Bioengineered airway epithelial grafts with mucociliary function based on collagen IV-and laminin-containing extracellular matrix scaffolds. Eur. Respir. J. 2020, 55, 1901200. [CrossRef] [PubMed]

68. Ibrahim, M.M.; Chen, L.; Bond, J.E.; Medina, M.A.; Ren, L.; Kokosis, G.; Selim, A.M.; Levinson, H. Myofibroblasts contribute to but are not necessary for wound contraction. Lab. Investig. 2015, 95, 1429-1438. [CrossRef] [PubMed]

69. Zhang, Q.; Liu, L.N.; Yong, Q.; Deng, J.C.; Cao, W.G. Intralesional injection of adipose-derived stem cells reduces hypertrophic scarring in a rabbit ear model. Stem Cell Res Ther 2015, 6, 145. [CrossRef] [PubMed]

70. Yoshizaki, A.; Yanaba, K.; Yoshizaki, A.; Iwata, Y.; Komura, K.; Ogawa, F.; Takenaka, M.; Shimizu, K.; Asano, Y.; Hasegawa, M.; et al. Treatment with rapamycin prevents fibrosis in tight-skin and bleomycin-induced mouse models of systemic sclerosis. Arthritis Rheum. 2010, 62, 2476-2487. [CrossRef]

71. Almine, J.F.; Wise, S.G.; Weiss, A.S. Elastin signaling in wound repair. Birth Defects Res. C Embryo Today 2012, 96, $248-257$. [CrossRef] [PubMed]

72. Wen, Q.; Mithieux, S.M.; Weiss, A.S. Elastin Biomaterials in Dermal Repair. Trends Biotechnol. 2020, 38, 280-291. [CrossRef] [PubMed]

73. O'Brien, F.J.; Harley, B.A.; Yannas, I.V.; Gibson, L. Influence of freezing rate on pore structure in freeze-dried collagen-GAG scaffolds. Biomaterials 2004, 25, 1077-1086. [CrossRef]

74. Haugh, M.G.; Jaasma, M.J.; O'Brien, F.J. The effect of dehydrothermal treatment on the mechanical and structural properties of collagen-GAG scaffolds. J. Biomed. Mater. Res. Part A 2009, 89, 363-369. [CrossRef]

75. Haugh, M.G.; Murphy, C.M.; McKiernan, R.C.; Altenbuchner, C.; O’Brien, F.J. Crosslinking and mechanical properties significantly influence cell attachment, proliferation, and migration within collagen glycosaminoglycan scaffolds. Tissue Eng. Part A 2011, 17, 1201-1208. [CrossRef] 